\title{
Salivary Iron (Fe) Ion Levels, Serum Markers of Anemia and Caries Activity in Pregnant Women Níveis de íon ferro ( $\mathrm{Fe}$ ) salivar, marcadores séricos de anemia, e atividade de cárie em mulheres grávidas
}

\author{
Elisa Miranda Costa ${ }^{1}$ Juliana Aires Paiva de Azevedo ${ }^{2}$ Rafiza Félix Marão Martins ${ }^{3}$ \\ Vandilson Pereira Rodrigues ${ }^{4}$ Cláudia Maria Coêlho Alves ${ }^{1}$ Cecília Cláudia Costa Ribeiro ${ }^{1}$ \\ Erika Bárbara Abreu Fonseca Thomaz ${ }^{1}$ \\ 1 Public Health Department, Universidade Federal do Maranhão, São \\ Luís, Maranhão, Brazil \\ 2 Post-graduation Program in Odonthology, Universidade Federal do \\ Maranhão, São Luís, Maranhão, Brazil \\ ${ }^{3}$ Department of Odonthology, Universidade Ceuma, São Luís, \\ Maranhão, Brazil \\ ${ }^{4}$ Department of Morphology, Universidade Federal do Maranhão, São \\ Luís, Maranhão, Brazil \\ Rev Bras Ginecol Obstet 2017;39:94-101. \\ Address for correspondence Elisa Miranda Costa, MSc, \\ Departamento de Saúde Pública, Universidade Federal do Maranhão, \\ Rua Barão de Itapary 155, 65020-070, São Luís, MA, Brazil \\ (e-mail: elisamirandac@hotmail.com).
}

\begin{abstract}
Keywords

- anemia

- saliva

- iron

- pregnancy

- tooth decay

Introduction Anemia is a very frequent event among pregnant women. There are evidences of differences in the incidence of dental caries between pregnant and nonpregnant women, but the relationship between salivary iron $(\mathrm{Fe})$ and serum markers of anemia and caries development has not been investigated.

Objective To evaluate the correlation between salivary (Fe) and serum iron (Fe, ferritin and hemoglobin) parameters in pregnant women with the development of dental caries. Methods A prospective cohort was conducted with 59 women. The outcome of interest was represented by new dental caries lesions during pregnancy, using the Nyvad criteria. Pregnant women were evaluated at three clinical times: up to the 16th week of gestational age (GA) (T1), in the last trimester of pregnancy (T2), and postpartum (T3), at the Mother and Child Unit of University Hospital of the Universidade Federal do Maranhão. A stimulated saliva sample was collected for biochemical analysis of salivary Fe, and a blood sample was collected early in the morning. The correlation between salivary and serum Fe was evaluated through the Pearson correlation test. Analysis of variance (ANOVA) and Kruskal-Wallis were used to compare the means of anemia parameters at different times. The Student's $t$ and Mann-Whitney tests were used to compare the anemia parameters between the groups of pregnant women (with and without new caries lesions).

Results Serum Fe concentrations were higher in the first trimester of pregnancy and lower after delivery $(p=0.036)$. It was also observed that the ferritin concentrations were higher in the first trimester and lower at the end of gestation $(p=0.011)$. There was no association between the expositions of salivary iron and anemia, and the development of dental caries. There was a positive correlation between serum Fe in $\mathrm{T} 1$ and salivary Fe in $\mathrm{T} 2(p<0.05)$. Conclusion The serum markers of anemia were more prevalent in the last trimester of pregnancy.
\end{abstract}

received

August 9, 2016

accepted

December 22, 2016

published online

March 14, 2017
DOI http://dx.doi.org/

10.1055/s-0037-1599217. ISSN 0100-7203.
Copyright (e 2017 by Thieme-Revinter

Publicações Ltda, Rio de Janeiro, Brazil

License terms

(c) $(1) \$$ 


\section{Resumo}

\section{Palavras-chave \\ - anemia \\ - saliva \\ - ferro \\ - gravidez \\ - cárie dentária}

Introdução A anemia é um evento muito frequente entre mulhres grávidas. Existem evidências de diferenças na incidência de cárie dentária entre mulheres grávidas e não grávidas, mas a relação entre o íon ferro (Fe) salivar, os marcadores séricos de anemia e o desenvolvimento de cárie não foi investigada.

Objetivo Avaliar a correlação entre os parâmetros salivares (Fe) e séricos (Fe, ferritina e hemoglobina) em gestantes e o desenvolvimento de cárie dentária.

Métodos Uma coorte prospectiva foi conduzida com 59 mulheres. O desfecho de interesse foi representado por novas lesões de cárie durante a gravidez, medido pelo critério Nyvad. Mulheres grávidas foram avaliadas em três tempos clínicos: até a 16a semana de idade gestacional (IG) (T1), no último trimestre de gravidez (T2), e no puerpério (T3), na Unidade Materno-infantil do Hospital Universitário da Universidade Federal do Maranhão. A amostra de saliva estimulada foi coletada para análise bioquímica de Fe salivar, e a amostra de sangue foi coletada no início da manhã. A correlação entre o Fe salivar e o Fe sérico foi avaliada através do teste de correlação de Pearson. Os testes ANOVA e Kruskal-Wallis foram utilizados para comparar parâmetros de anemia em diferentes momentos. Os testes $t$ de Student e Mann-Whitney foram utilizados para comparar os parâmetros da anemia entre os grupos de gestantes (com e sem lesões de cárie).

Resultados As concentrações séricas de Fe foram maiores no primeiro trimestre de gestação e menores após o parto $(p=0,036)$. Observou-se também que as concentrações de ferritina foram maiores no primeiro trimestre e menores no final da gestação $(p=0,011)$. Não houve associação entre as exposições e o desenvolvimento de cárie dentária. Houve correlação positiva entre o Fe sérico em T1 e o Fe salivar em T2 $(p<0,05)$.

Conclusão Os marcadores séricos de anemia foram mais prevalentes no último trimestre de gestação.

\section{Introduction}

There is evidence of increased incidence of dental caries during pregnancy, ${ }^{1,2}$ potentially due to significant differences in dental caries indicators between pregnant and non-pregnant women. ${ }^{3}$ The state of activity of carious lesions during pregnancy can be influenced by behavioral factors (frequency of brushing and flossing, changes in dietary patterns, occurrence of vomiting $)^{4,5}$ and by systemic factors (immunological, hormonal and metabolic changes). ${ }^{1}$

It is suggested that during pregnancy, a period in which there is a strong mineral mobilization from maternal stores to generate fetal development, ${ }^{6}$ there is a possibility that these minerals are displaced from the pregnant women's teeth, thus increasing the risk of dental caries. ${ }^{6,7}$ This hypothesis is based on the "maternal depletion syndrome," whereby there can be maternal nutritional depletion, especially in the case of short interval between pregnancies. ${ }^{6}$ But there is not enough evidence to establish this relationship.

In this period, local factors such as saliva may interfere with the development of dental caries. During pregnancy, decreased $\mathrm{pH}$ and buffering capacity are common due to episodes of vomiting and reduced salivary flow. ${ }^{1,4}$ This may contribute to consider this population as a group more vulnerable to oral health disorders.
Inorganic components, such as sodium $(\mathrm{Na})$, potassium $(\mathrm{K})$, Calcium $(\mathrm{Ca})$, chloride $\left(\mathrm{Cl}_{2}\right)$, bicarbonate $\left(\mathrm{HCO}_{3}{ }^{-}\right)$and phosphate (PO43-) determine the relative fluid saturation respected to hydroxyapatite. Their concentrations vary in stimulated and unstimulated saliva. ${ }^{8}$ Some of these biochemical markers present in saliva, such as $\mathrm{Ca}$, phosphorus $(\mathrm{P})$ and fluorine $(\mathrm{F})$, play an important role in the process of enamel and dentin remineralization..$^{6,7,9-12}$ Although these elements have been more widely studied, it was also observed that iron $(\mathrm{Fe})$ ion is a protective element against dental caries. ${ }^{13,14}$

The protective mechanism of $\mathrm{Fe}$ ion with respect to dental caries is not very clear. ${ }^{13}$ It is possible that immunological and microbiological factors are involved. ${ }^{14,15} \mathrm{How}$ ever, there are some hypotheses about the role of $\mathrm{Fe}$ in modulating the activity of dental caries: it may increase enamel resistance to demineralization; it may have an antibacterial effect; and it may even have a specific effect on decreasing the activity of glycosyltransferases (GTFs) from Streptococcus mutans. However, studies on this subject are not conclusive.

The aim of this study was to investigate the association between $\mathrm{Fe}$ levels in saliva and serum, hemoglobin and ferritin levels, and the risk of dental caries development in pregnant women. 


\section{Methods}

\section{Design, Area, Study Population and Ethical Considerations}

This prospective cohort study was conducted with a sample of pregnant women in the city of São Luís, Maranhão, in Brazil. This research was approved by the Ethics Research Committee of the Hospital Universitário of Universidade Federal do Maranhão in February of 2010, under the protocol $004417 / 2010-20$. Only pregnant women who agreed to participate and signed the informed consent form (ICF) were evaluated.

\section{Sample Design, Inclusion and Exclusion Criteria}

Using the Epi-Info software, version 6.0 (Center for Disease Control and Prevention, Atlanta, GA, USA), it was estimated that a sample of 39 pregnant women would allow us $80 \%$ of power to detect differences between exposed and nonexposed individuals, considering an incidence of the dental caries of $68.2 \%$ (estimated in a pilot study), and a 2:1 ratio between unexposed and exposed individuals, with a significance level of $5 \%$. We added $10 \%$ to compensate for possible losses, and a minimum sample of 42 pregnant women was obtained (28 exposed and 14 unexposed to tooth decay).

Women were recruited at the Mother and Child Unit of Hospital Universitário of Universidade Federal do Maranhão during a prenatal visit. The recruitment period lasted 24 months, from July 2011 to June 2013. During this period, the maternity was visited daily by the researches, who registered all pregnant women in prenatal care.

Only women with a singleton pregnancy and gestational age (GA) up to 16 weeks were included. Individuals with endocrine-metabolic diseases, kidney, liver and cardiocirculatory dysfunctions, those with pregnancies considered of high risk, as well as those with premature births were excluded. Gestational age was assessed using ultrasonography performed in a routine service in the first trimester of pregnancy and, when not available, the last menstrual period or clinical estimate. Eligible patients were included in the study and followed until the postpartum period.

\section{Definition of Variables and Data Collection}

The pregnant women were interviewed, and medical and dental examinations for general health and to detect the presence of dental caries were performed. Blood and saliva were also collected for biochemical evaluations. For the interviews, a previously tested questionnaire was used. The data from the clinical examinations were recorded on a sheet made for this research. Medical data were also collected, such as the GA and the general health of the pregnant women.

The participants were evaluated at three clinical times: up to the 16th week of GA(T1), in the last trimester of pregnancy (T2), and in postpartum (T3). At all determined clinical times, the patients were submitted to an interview, to medical and dental examinations to evaluate the general health and detect the presence of dental caries, and blood and saliva collections for biochemical assessments. Preferably,
T3 occurred at the hospital in the early days after delivery. If the mother had been discharged before the evaluation, she was invited to return to the hospital for na examination during the medical follow-up visit.

The choice of these gestational periods to carry out the biochemical assessments was due to the evidence that in the first trimester there is high absorption/low except of minerals to make up the maternal reserves. In the last trimester, there is a sudden increase in the fetus weight mainly at the expense of bone mass gain, with large mobilization of micronutrients from the maternal reserves for the formation of the baby, which can lead to maternal nutritional depletion if there is no sufficient intake/reserves to meet this demand. ${ }^{16,17}$

Dental examinations were performed by previously trained staff, under artificial light, after drying the teeth, with the pregnant woman sitting in the dental chair, using a millimeter probe (Hu-Friedy, Chicago, USA) and a mouth mirror recommended by the World Health Organization (WHO). All instruments were sterilized and individually packed. The clinical examinations were recorded on specific data sheets. The dependent variable was the incidence of dental caries in pregnant women. The presence of caries was assessed using the Nyvad criteria. The presence of cariesactive white spot lesions, characterized as opaque spots, with soft and rough consistency, determining the current activity of caries, was observed. ${ }^{18}$ With this criterion, therefore, we are capable of identifying the disease while still in its early stages, and it is more suitable for studies with a short followup period. ${ }^{18}$

The teeth were classified as healthy (codes 0 to 7 ), with inactive (codes 4, 5, 6 and 9) or active caries (codes 1, 2, 3 and 8). ${ }^{18}$ The average decayed teeth (active + inactive lesions) were estimated for each individual. The sample was therefore classified into group 1 (G1), with no new caries lesions; and group 2 (G2), with the incidence of the disease.

The participants were told not to eat, drink or perform oral hygiene procedures in a time interval less than 1 hour prior to the saliva collection. Stimulated saliva samples were collected by asking the paeticipants to chew on a paraffin blade (Parafilm, Bemis, Neenah, USA) of $5 \times 5 \mathrm{~cm}$ in size. The subjects were instructed to gently tilt the head forward and not to talk or swallow the saliva present in the mouth. Every minute, the participant spit the amount of accumulated saliva into a Falcon (Inlab, São Paulo, Brazil) collection tube graduate of $5 \mathrm{~mL}$ to obtain a volume of 1 to $2 \mathrm{~mL}$.

The samples were stored on ice and transported to processing in a time period shorter than two hours. The samples were centrifuged for 7 minutes at 7,000 rpm in a Falcon tube centrifuge. After this procedure, the supernatant volume was stored in $1.5 \mathrm{ml}$ Eppendorf (Hamburg, Germany) tubes and frozen at $-80^{\circ} \mathrm{C}$ for subsequent biochemical analysis.

Salivary Fe quantification $(\mathrm{mg} / \mathrm{dL}), \mathrm{K}(\mathrm{mmol} / \mathrm{L})$ was conducted in triplicate with the colorimetric method and specific reagents (kit produced by Doles, Goiânia, Brazil). The subtraction of the control solution (without sample), 
followed by the multiplication by factor for the standard solution was used as a reference for calculating the converted measurement units. The reading of Fe absorbance in a $490 \mathrm{~nm}$ wavelength occurred after the homogenization of $10 \mu$ of the sample with $1 \mathrm{ml}$ of the color reagent (Ferrozine).

The other covariates included: a) sociodemographic data: schooling ( $<8$ years of schooling, $\geq 8$ years of schooling), head of the family (pregnant women, partner or other), maternal marital status (with or without partner), social class (A/B, C or $\mathrm{D} / \mathrm{E}$ ) according to the criteria of the Brazilian Market Reasearch Association (ABEP, 2008) ${ }^{19}$, access to basic sanitation (yes or no); b) gestational health: history of vomiting in the current pregnancy (yes or no), visit to the dentist (yes or no), use of antianemic (yes or no); and c) practices related to oral health: daily tooth brushing frequency ( $\geq 3$ or $\leq 3$ times), habit of brushing teeth after meals (yes or no), use of mouthwash (yes or no), use of dental floss (yes or no), dental appointment during pregnancy (yes or no), and access to fluoride (topical fluoride application, toothpaste, mouthwash, tablets) during pregnancy (yes or no).

\section{Methodological Care for Measurement Bias}

A manual with instructions on filling out the data collection instruments and the dental examination methods and criteria for the classification of variables was elaborated. Intra and interexaminer concordance (Kappa and intraclass correlation coefficient) was evaluated. Only evaluators who have obtained agreements $\geq 0.80$ remained on the team. A pilot study was conducted at every stage of the research before starting data collection.

\section{Data Analysis and Processing}

Analyses were performed using the Stata software, version 14.0 (Stata Corp., College Station, Texas, USA). Descriptive statistics was processed using absolute frequency, relative frequency, average, standard deviation, median and interquartile interval. Chi-square or Fisher exact tests were used to analyze the difference in the frequencies of the categorical variables between the groups. For the numerical variables, the normality of the sample distribution was assessed through the Shapiro-Wilk test. The Student's t-test (between groups at the same time) was selected for the comparative analysis of the numerical variables. To analyze variations in serum hemoglobin, ferritin, erythrocyte, serum Fe and salivary Fe levels, the Tukey Test, Kruskal-Wallis, Newman-Keuls and analysis of variance (ANOVA) were used. The Pearson coefficient was calculated to assess the correlation between the salivary Fe ion concentration and the collected serum Fe. The significance level adopted was $5 \%$.

\section{Results}

Total 539 pregnant women were screened at baseline. Of these, eighty-three (83) were eligible and agreed to participate in the study, and went through an interview, a clinical examination and a blood collection at $\mathrm{T} 1$, and 56 of them (67.5\%) returned for evaluations in T2 and T3, constituting the final sample of this study.
- Table 1 expresses the socioeconomic variables and the frequency of oral hygiene habits in pregnant women between the two caries activity groups. Most pregnant women assessed: had 8 or more years of schooling (79.6\%); lived with partners (92.7\%) who were the head of the family in $60 \%$ of cases; had no access to basic sanitation (64.2\%); belonged to economic class $\mathrm{C}(58.9 \%)$; reported Fe supplement use during pregnancy (85.7\%); reported no dental visits (89.3\%); and had not underwent topical fluoride application in a dental office (91.1\%). Regarding oral hygiene habits, $54.6 \%$ of the pregnant women reported. brushing their teeth 3 or more times per day, and $69.6 \%$ only after meals; The daily use of mouthwashes and dental floss was reported by $80.4 \%$ and $44 \%$ of the sample. There were no statistically significant differences for these variables among caries activity groups.

The comparative analysis of serum biomarkers among caries activity groups in the pregnant women is expressed in - Table 2. We observed that the serum ferritin levels were statistically higher at postpartum than in the first and last trimesters of gestation $(p=0.018)$. We also observed that the serum Fe level was statistically higher $(p<0.005)$ in the first trimester of pregnancy $(106.4 \pm 27.5)$ compared with the last trimester $(90.0 \pm 40.5)$ and after delivery $(86.3 \pm 26.3)$. On the other hand, statistically significant differences in salivary Fe levels were not observed among the three time periods $(p=0.170)$. The hemoglobin and hematocrit levels showed no statistically significant variations in time periods analyzed ( $\mathrm{p} \geq 0.05$ ). The analysis also suggests that there are no statistically significant differences in the levels of these biomarkers among caries activity groups.

Furthermore, the linear correlation measures between serum and salivary Fe levels in the three clinical time periods were calculated ( - Table 3 ). There was a direct correlation between serum Fe in $\mathrm{T} 1$ and salivary Fe in T2 $(r=0.99$; $p=0.045)$. No other statistically significant correlations were observed.

\section{Discussion}

The findings of this study suggest that serum Fe concentrations were higher in the first trimester of pregnancy and lower after delivery, and that serum ferritin concentrations were lower in $\mathrm{T} 2$ and higher in T3. On the other hand, salivary concentrations were higher in the T2 and also lower in T3. There was a positive correlation between serum Fe in $\mathrm{T} 1$ and salivary Fe in T2.

Pregnant women with higher schooling, higher socioeconomic status and included in medical prenatal care from the first trimester of pregnancy were more likely to adopt preventive oral health measures and perform dental treatments, ${ }^{19-21}$ therefore showing lower frequency of oral problems such as dental caries. However, in our sample, socioeconomic factors did not differ between groups with and without dental caries, showing that groups are homogeneous and comparable. This reduces potential confounding biases.

Serum Fe concentrations had significant changes during and after pregnancy, with higher values in $\mathrm{T} 1$ and lower in $\mathrm{T} 3$. 
98 Salivary Iron (Fe) lon Levels Costa et al.

Table 1 Incidence of dental caries according to socioeconomic conditions and oral hygienic habits

\begin{tabular}{|c|c|c|c|c|c|c|c|}
\hline \multirow{2}{*}{$\begin{array}{l}\text { Variables } \\
\text { Qualitative variables }\end{array}$} & \multicolumn{2}{|c|}{ Total } & \multicolumn{2}{|c|}{$\begin{array}{l}\text { G1 } \\
\text { New caries }=0\end{array}$} & \multicolumn{2}{|c|}{$\begin{array}{l}\text { G2 } \\
\text { New caries } \geq 1\end{array}$} & \multirow[t]{2}{*}{$p$-value } \\
\hline & $\mathrm{n}^{*}$ & $\%$ & $\mathrm{n}$ & $\%$ & $\mathrm{n}$ & $\%$ & \\
\hline \multicolumn{8}{|l|}{ Schooling } \\
\hline$<8$ years school & 10 & 20.4 & 6 & 60.0 & 4 & 40.0 & \multirow[t]{2}{*}{$0.496^{\mathrm{a}}$} \\
\hline$\geq 8$ years & 39 & 79.6 & 18 & 46.1 & 21 & 53.9 & \\
\hline \multicolumn{8}{|l|}{ Marital status } \\
\hline With partner & 51 & 92.7 & 22 & 43.1 & 29 & 56.9 & \multirow[t]{2}{*}{$0.320^{\mathrm{a}}$} \\
\hline Without partner & 4 & 7.3 & 3 & 75.0 & 1 & 25.0 & \\
\hline \multicolumn{8}{|l|}{ Head of the family } \\
\hline Pregnant woman & 7 & 12.7 & 2 & 28.6 & 5 & 71.4 & \multirow[t]{3}{*}{$0.541^{\mathrm{a}}$} \\
\hline Partner & 33 & 60.0 & 17 & 51.5 & 16 & 48.5 & \\
\hline Other & 15 & 27.3 & 6 & 40.0 & 9 & 60.0 & \\
\hline \multicolumn{8}{|l|}{ Basic sanitation } \\
\hline Yes & 19 & 35.8 & 6 & 31.6 & 13 & 68.4 & \multirow[t]{2}{*}{$0.194^{b}$} \\
\hline No & 34 & 64.2 & 17 & 50 & 17 & 50.0 & \\
\hline \multicolumn{8}{|l|}{$\mathrm{BECC}^{* *}$} \\
\hline A-B & 14 & 25.0 & 9 & 64.3 & 5 & 35.7 & \multirow[t]{3}{*}{$0.278^{\mathrm{a}}$} \\
\hline$C$ & 33 & 58.9 & 14 & 42.4 & 19 & 57.6 & \\
\hline D-E & 9 & 16.1 & 3 & 33.3 & 6 & 66.7 & \\
\hline \multicolumn{8}{|l|}{ Use of anti-anemic } \\
\hline Yes & 48 & 85.7 & 21 & 47.3 & 27 & 56.3 & \multirow[t]{2}{*}{$0.451^{\mathrm{a}}$} \\
\hline No & 8 & 14.3 & 5 & 62.5 & 3 & 37.5 & \\
\hline \multicolumn{8}{|l|}{ Nausea } \\
\hline Yes & 47 & 85.5 & 23 & 48.9 & 24 & 51.1 & \multirow[t]{2}{*}{$0.708^{\mathrm{a}}$} \\
\hline No & 8 & 14.5 & 3 & 37.5 & 5 & 62.5 & \\
\hline \multicolumn{8}{|l|}{ Visit to the dentist } \\
\hline Yes & 6 & 10.7 & 3 & 50.0 & 3 & 50.0 & \multirow[t]{2}{*}{$0.509^{\mathrm{a}}$} \\
\hline No & 50 & 89.3 & 23 & 46.0 & 27 & 40.0 & \\
\hline \multicolumn{8}{|c|}{ TFA performed at the dental office } \\
\hline Yes & 5 & 8.9 & 2 & 40.0 & 3 & 60.0 & \multirow[t]{2}{*}{$0.569^{\mathrm{a}}$} \\
\hline No & 51 & 91.1 & 24 & 47.1 & 27 & 52.9 & \\
\hline \multicolumn{8}{|c|}{ Frequency of daily tooth brushing } \\
\hline$\geq 3$ & 30 & 54.6 & 14 & 46.7 & 16 & 53.3 & $0.921^{\mathrm{b}}$ \\
\hline$\leq 3$ & 25 & 45.4 & 12 & 48.0 & 13 & 52 & \\
\hline Brush after meals & & & & & & & \\
\hline Yes & 39 & 69.6 & 17 & 43.6 & 22 & 56.4 & $0.519^{b}$ \\
\hline No & 17 & 30.4 & 9 & 52.9 & 8 & 47.1 & \\
\hline Use of dental floss & & & & & & & \\
\hline Yes & 22 & 44.0 & 11 & 50.0 & 11 & 50.0 & $0.449^{b}$ \\
\hline No & 28 & 56.0 & 11 & 39.3 & 17 & 60.7 & \\
\hline Use of mouthwash & & & & & & & \\
\hline Yes & 41 & 80.4 & 19 & 46.3 & 22 & 53.7 & $0.835^{\mathrm{b}}$ \\
\hline No & 10 & 19.6 & 5 & 50.0 & 5 & 55 & \\
\hline
\end{tabular}

Abbreviations: BECC, Brazilian Economic Classification Criteria; TFA, topical fluoride application.

${ }^{*}$ Total number is not equal to 56 due to loss of information for some variables.

${ }^{* *}$ BECC is determined by the Brazilian Market Research Association (Associação Brasileira de Empresas de Pesquisa [ABEP]).

${ }^{a}$ Fisher exact Test.

${ }^{\mathrm{b}}$ Chi-square Test. 
Table 2 Levels of hemoglobin, erythrocyte, ferritin and Fe (serum and salivary) in pregnant women with and without new dental caries lesions

\begin{tabular}{|c|c|c|c|c|c|c|c|c|}
\hline \multirow[t]{3}{*}{ Variables } & \multirow{2}{*}{\multicolumn{2}{|c|}{ Total }} & \multirow[t]{3}{*}{$p$} & \multicolumn{4}{|c|}{ Dental caries activity } & \multirow[t]{3}{*}{$p$} \\
\hline & & & & \multicolumn{2}{|c|}{ Yes (G1) } & \multicolumn{2}{|l|}{ No (G2) } & \\
\hline & $\begin{array}{l}\text { mean } \\
\text { (SD) }\end{array}$ & $\begin{array}{l}\text { average } \\
\text { (Q1-Q3) }\end{array}$ & & $\begin{array}{l}\text { mean } \\
(S D)\end{array}$ & $\begin{array}{l}\text { average } \\
\text { (Q1-Q3) }\end{array}$ & $\begin{array}{l}\text { mean } \\
\text { (SD) }\end{array}$ & $\begin{array}{l}\text { average } \\
\text { (Q1-Q3) }\end{array}$ & \\
\hline \multicolumn{9}{|c|}{ Hemoglobin } \\
\hline $\mathrm{T} 1$ & $\begin{array}{l}12.0 \\
(1.4)\end{array}$ & $\begin{array}{l}12.5 \\
(11.3-12.8)^{a}\end{array}$ & \multirow[t]{3}{*}{0.199} & $\begin{array}{l}12.4 \\
(0.3)\end{array}$ & $\begin{array}{l}12.4 \\
(12.0-12.7)\end{array}$ & $\begin{array}{l}13.0 \\
(1.0)\end{array}$ & $\begin{array}{l}12.6 \\
(12.5-13.6)\end{array}$ & 0.306 \\
\hline $\mathrm{T} 2$ & $\begin{array}{l}12.4 \\
(1.8)\end{array}$ & $\begin{array}{l}12.3 \\
(11.4-13.4)^{a}\end{array}$ & & $\begin{array}{l}12.4 \\
(0.9)\end{array}$ & $\begin{array}{l}12.3 \\
(11.5-13.4)\end{array}$ & $\begin{array}{l}11.7 \\
(1.9)\end{array}$ & $\begin{array}{l}11.4 \\
(9.9-13.3)\end{array}$ & 0.442 \\
\hline T3 & $\begin{array}{l}14.2 \\
(0.9)\end{array}$ & $\begin{array}{l}14.2 \\
(13.6-14.9)^{a}\end{array}$ & & - & - & $\begin{array}{l}14.2 \\
(0.9)\end{array}$ & $\begin{array}{l}14.2 \\
(13.6-14.9)\end{array}$ & - \\
\hline \multicolumn{9}{|c|}{ Erythrocyte } \\
\hline $\mathrm{T} 1$ & $\begin{array}{l}4.2 \\
(0.5)\end{array}$ & $\begin{array}{l}4.2 \\
(4.1-4.3)^{\mathrm{a}}\end{array}$ & \multirow[t]{3}{*}{0.419} & $\begin{array}{l}4.4 \\
(0.3)\end{array}$ & $\begin{array}{l}4.3 \\
(4.2-4.7)\end{array}$ & $\begin{array}{l}4.5 \\
(0.6)\end{array}$ & $\begin{array}{l}4.3 \\
(4.2-4.9)\end{array}$ & 0.727 \\
\hline $\mathrm{T} 2$ & $\begin{array}{l}4.2 \\
(0.7)\end{array}$ & $\begin{array}{l}4.1 \\
(3.8-4.7)^{a}\end{array}$ & & $\begin{array}{l}4.1 \\
(0.4)\end{array}$ & $\begin{array}{l}3.9 \\
(3.9-4.5)\end{array}$ & $\begin{array}{l}4.0 \\
(0.9)\end{array}$ & $\begin{array}{l}3.8 \\
(3.6-4.5)\end{array}$ & 0.556 \\
\hline T3 & $\begin{array}{l}4.8 \\
(0.1)\end{array}$ & $\begin{array}{l}4.8 \\
(4.7-4.9)^{\mathrm{a}}\end{array}$ & & - & - & $\begin{array}{l}4.8 \\
(0.1)\end{array}$ & $\begin{array}{l}4.8 \\
(4.7-4.9)\end{array}$ & - \\
\hline \multicolumn{9}{|l|}{ Ferritin } \\
\hline T1 & $\begin{array}{l}52.5 \\
(53.8)\end{array}$ & $\begin{array}{l}36.3 \\
(28.9-58.9)^{a}\end{array}$ & \multirow[t]{3}{*}{0.011} & $\begin{array}{l}43.3 \\
(19.9)\end{array}$ & $\begin{array}{l}36.9 \\
(29.9-61.6)\end{array}$ & $\begin{array}{l}49.3 \\
(45.7)\end{array}$ & $\begin{array}{l}31.3 \\
(28.3-49.7)\end{array}$ & 0.386 \\
\hline $\mathrm{T} 2$ & $\begin{array}{l}44.5 \\
(53.7)\end{array}$ & $\begin{array}{l}22.4 \\
(13.3-49.0)^{\mathrm{a}}\end{array}$ & & $\begin{array}{l}90.1 \\
(95.6)\end{array}$ & $\begin{array}{l}34.1 \\
(23.5-153.90\end{array}$ & $\begin{array}{l}32.3 \\
(34.3)\end{array}$ & $\begin{array}{l}17.8 \\
(11.7-38.5)\end{array}$ & 0.147 \\
\hline T3 & $\begin{array}{l}61.8 \\
(43.5)\end{array}$ & $\begin{array}{l}43.9 \\
(35.6-83.3)^{b}\end{array}$ & & $\begin{array}{l}68.9 \\
(40.6)\end{array}$ & $\begin{array}{l}49.1 \\
(40.7-95.9)\end{array}$ & $\begin{array}{l}49.9 \\
(33.4)\end{array}$ & $\begin{array}{l}41.9 \\
(27.0-68.3)\end{array}$ & 0.129 \\
\hline \multicolumn{9}{|l|}{ Serum Fe } \\
\hline $\mathrm{T} 1$ & $\begin{array}{l}106.4 \\
(27.5)\end{array}$ & $\begin{array}{l}107.3 \\
(93.0-116.4)^{b}\end{array}$ & \multirow[t]{3}{*}{0.036} & $\begin{array}{l}97.0 \\
(27.1)\end{array}$ & $\begin{array}{l}94.3 \\
(86.0-115.0)\end{array}$ & $\begin{array}{l}104.9 \\
(31.2)\end{array}$ & $\begin{array}{l}111.7 \\
(83.5-127.0)\end{array}$ & 0.582 \\
\hline $\mathrm{T} 2$ & $\begin{array}{l}90.0 \\
(40.5)\end{array}$ & $\begin{array}{l}91.0 \\
(61.0-123.0)^{a}\end{array}$ & & $\begin{array}{l}103.5 \\
(29.4)\end{array}$ & $\begin{array}{l}97.5 \\
(91.0-135.0)\end{array}$ & $\begin{array}{l}84.4 \\
(46.9)\end{array}$ & $\begin{array}{l}76.0 \\
(49.0-123.0)\end{array}$ & 0.363 \\
\hline $\mathrm{T} 3$ & $\begin{array}{l}86.3 \\
(26.3)\end{array}$ & $\begin{array}{l}87.5 \\
(63.0-101.0)^{a}\end{array}$ & & $\begin{array}{l}93.1 \\
(23.9)\end{array}$ & $\begin{array}{l}95.0 \\
(81.3-106.0)\end{array}$ & $\begin{array}{l}81.1 \\
(24.6)\end{array}$ & $\begin{array}{l}86.2 \\
(62.0-94.6)\end{array}$ & 0.156 \\
\hline \multicolumn{9}{|l|}{ Salivary Fe } \\
\hline T1 & $\begin{array}{l}57.8 \\
(77.3)\end{array}$ & $\begin{array}{l}9.9 \\
(3.3-135.0)^{a}\end{array}$ & \multirow[t]{3}{*}{0.170} & $\begin{array}{l}3.8 \\
(5.4)\end{array}$ & $\begin{array}{l}3.8 \\
(0.0-7.6)\end{array}$ & - & - & - \\
\hline $\mathrm{T} 2$ & $\begin{array}{l}93.1 \\
(175.7)\end{array}$ & $\begin{array}{l}25.0 \\
(10.0-60.0)^{a}\end{array}$ & & $\begin{array}{l}14.3 \\
(11.4)\end{array}$ & $\begin{array}{l}13.6 \\
(5.8-22.8)\end{array}$ & $135.9(144.7)$ & $\begin{array}{l}87.6 \\
(37.6-234.2)\end{array}$ & 0.145 \\
\hline T3 & $\begin{array}{l}42.3 \\
(124.3)\end{array}$ & $\begin{array}{l}5.9 \\
(1.7-19.9)^{a}\end{array}$ & & $\begin{array}{l}4.4 \\
(6.7)\end{array}$ & $\begin{array}{l}0.0 \\
(0.0-6.7)\end{array}$ & $16.0(13.4)$ & $\begin{array}{l}13.5 \\
(5.0-27.0)\end{array}$ & 0.130 \\
\hline
\end{tabular}

Abbreviations: Av., average; Fe, iron; SD, standard deviation; T1, $1^{\text {st }}$ trimester; T2, $3^{\text {rd }}$ trimester; T3, postpartum.

Note: Analysis of variance (ANOVA) or Kruskal-Wallis tests were used in the comparative analysis of the biomarkers of the pregnant women at the three clinical times. Student's t or Mann-Whitney tests were used in the comparative analysis of the biomarkers among caries activity groups at the same time. Different superscript lowercase letters ( $a$ and $b$ ) indicate statistically significant differences in the biomarker at the different clinical times (Tukey and Student-Newman-Keuls test).

This result is in agreement with the literature. In addition, the maternal Fe reserves are formed in the first trimester of pregnancy, when larger amounts of this substance are required for the maturation and the biological functions of the fetus during the last trimester of pregnancy. ${ }^{22-24}$ The lower serum Fe values observed in T3 may be associated with the presence of anemia before and during pregnancy and blood loss during delivery. ${ }^{22-25}$

Serum ferritin concentrations varied significantly over the three clinical times, being lower in T2 and higher in T3. Iron deficiency developed in three phases. ${ }^{26,27}$ In the first phase, there is a decrease in serum ferritin, which is directly 
Table 3 Pearson correlation coefficient between salivary and serum Fe at different evaluation times

\begin{tabular}{|c|c|c|c|c|c|c|c|}
\hline \multirow[t]{2}{*}{ Variables } & \multirow[t]{2}{*}{ Times } & \multicolumn{3}{|c|}{ Serum Fe } & \multicolumn{3}{|c|}{ Salivary Fe } \\
\hline & & $\mathrm{T} 1$ & $\mathrm{~T} 2$ & $\mathrm{T3}$ & $\mathrm{T} 1$ & $\mathrm{~T} 2$ & T3 \\
\hline \multirow[t]{3}{*}{ Serum Fe } & $\mathrm{T} 1$ & 1.0 & & & & & \\
\hline & $\mathrm{T} 2$ & 0.32 & 1.0 & & & & \\
\hline & T3 & -0.23 & 0.12 & 1.0 & & & \\
\hline \multirow[t]{3}{*}{ Salivary Fe } & $\mathrm{T} 1$ & -0.39 & -0.39 & -0.55 & 1.0 & & \\
\hline & $\mathrm{T} 2$ & 0.99 & -0.16 & -0.01 & -0.06 & 1.0 & \\
\hline & T3 & -0.40 & 0.12 & -0.22 & -0.64 & -0.25 & 1.0 \\
\hline
\end{tabular}

Abbreviations: Fe, iron; T1, $1^{\text {st }}$ trimester; $\mathrm{T} 2,3^{\text {rd }}$ trimester; $\mathrm{T} 3$, postpartum.

related to the available Fe reserves. ${ }^{27}$ In the second phase, there is a decline in serum Fe concentration and increased Fe binding capacity. ${ }^{27}$ In the third, there is a restriction in the synthesis of hemoglobin. Therefore, it seems that ferritin is the most sensitive serum parameter in the diagnosis of anemia. ${ }^{28,29}$ Over the gestational periods, there is an increasing demand for Fe from the developing fetus; therefore, the decrease in ferritin in the last trimester of pregnancy is biologically plausible. It has been hypothesized that after delivery, the maternal reserves that are available to the body are partially replenished, explaining the higher serum ferritin levels found in $\mathrm{T} 3$.

There was no difference in serum and salivary levels according to the incidence of dental caries. However, a study performed in Northern India evaluated Fe, magnesium (Mg), copper $(\mathrm{Cu})$ and $\mathrm{F}$ levels present in the saliva of children and found no consistent relationship between the concentration of these ions and dental caries. ${ }^{30}$ Moreover, a study in Malaysia $^{31}$ analyzing variations in $\mathrm{Cu}, \mathrm{Mg}$, Fe, and zinc ( $\left.\mathrm{Zn}\right)$ concentrations found positive correlations between $\mathrm{Cu}$ and Zn concentrations in children with dental caries. The data obtained show diverges greatly from the literature; moreover, this interaction had not been investigated in pregnant women, which is an original feature of this of study in the analysis of the hypothesis of this association.

The Fe concentrations in the saliva were higher in the T2 and T3. Saliva has a protective effect up to the limit of pH 5.5. Lower values create conditions for increased solubility and dissolution of enamel crystals. When critical $\mathrm{pH}$ periods become more common, there may be a predominance of loss of tooth ions, forming caries lesions. ${ }^{32}$ It is hypothesized that tooth demineralization occurs, and the concentration of Fe ions in the saliva is higher, explaining the higher values of this ion during T2 and the lower values in T3.

It was observed that the higher the serum Fe concentration in T1, the higher the salivary Fe concentration in T2. There is high absorption/low exception of minerals to compose a maternal reserve in the first trimester. ${ }^{26}$ Thus, it is possible that the Fe levels are higher in early pregnancy compared with subsequent trimesters and soon after delivery. ${ }^{22-24}$ In addition, the second and third trimesters are periods that require a greater metabolic use of minerals for the growth and maturation of the fetus. ${ }^{16}$
Regarding the highest salivary Fe concentration in $\mathrm{T} 2$, this data differs from the literature, in which the presence of the Fe ion acts in reducing the glycosyltransferases (GTFs) ${ }^{33}$ and extracellular polysaccharide synthesis (EPS), ${ }^{33}$ both virulence mechanisms of $S$. mutans. Furthermore, Fe supplementation led to the inhibition of the progression of dental caries, ${ }^{34}$ and increased Fe concentrations decreased enamel demineralization..$^{13}$ However, it is suggested that differences in the salivary composition during pregnancy, such as reduced $\mathrm{pH}$, higher concentration of mucins and physiological anemia may interfere with the biochemical composition of saliva, leading to the increased Fe ion concentration present in the sample and to the susceptibility to dental caries.

It is important to point out some limitations of the study, such as the small sample size, the losses, and the fact that it was selected for convenience. Furthermore, the microbiological analysis of the biofilm, the quantification of $\mathrm{Fe}$ ions present, salivary flow tests, and an analysis of the buffering capacity were not performed, which are interesting resources to monitor the susceptibility to local diseases like periodontitis and dental caries, ${ }^{35,36}$ and systemic diseases such as infectious, malignant, hereditary, autoimmune and endocrine disorders. They are also interesting resources to monitor the evaluation of therapeutic drug levels. ${ }^{35}$

However, the study presents the following strengths: the criterion of choice for the diagnosis of dental caries (Nyvad criteria) allows for the identification of lesions in the early stages of the disease. The study design was a prospective cohort, in which pregnant women were evaluated at three clinical time periods. Moreover, the recruitment was of a homogeneous population, in which socioeconomic and behavioral factors did not differ, reducing the confounding bias, so the results are independent of these factors.

This study presented many innovative elements, as it aimed at evaluating Fe ions present in saliva, dental caries activity and the correlation with anemia in pregnant women longitudinally, something that had not been done so far. Thus, this topic should be further studied.

There was a direct correlation between serum Fe in the first trimester and salivary Fe in the last trimester, and the serum markers of anemia were more prevalent in the last trimester of pregnancy. 


\section{Acknowledgments}

The study was supported in part by Fundação de Amparo à Pesquisa e Desenvolvimento Científico do Maranhão (FAPEMA). The authors have no conflict of interest to declare.

\section{References}

1 Martínez-Pabón MC, Martínez Delgado CM, López-Palacio AM, Patiño-Gómez LM, Arango-Pérez EA. The physicochemical and microbiological characteristics of saliva during and after pregnancy. Rev Salud Publica (Bogota) 2014;16(01):128-138

2 Neiswanger K, McNeil DW, Foxman B, et al. Oral health in a sample of pregnant women from Northern Appalachia (2011-2015). Int J Dent 2015;2015:469376

3 Saluja P, Shetty V, Dave A, Arora M, Hans V, Madan A. Comparative evaluation of the effect of menstruation, pregnancy and menopause on salivary flow rate, $\mathrm{pH}$ and gustatory function. J Clin Diagn Res 2014;8(10):ZC81-ZC85

4 Minozzi F, Chipaila N, Unfer V, Minozzi M. Odontostomatological approach to the pregnant patient. Eur Rev Med Pharmacol Sci 2008;12(06):397-409

5 Reis DM, Pitta DR, Ferreira HMB, de Jesus MC, de Moraes ME, Soares MG. Health education as a strategy for the promotion of oral health in the pregnancy period. Cien Saude Colet 2010; 15(01):269-276

6 Zhang L, Weir MD, Hack G, Fouad AF, Xu HH. Rechargeable dental adhesive with calcium phosphate nanoparticles for long-term ion release. J Dent 2015;43(12):1587-1595

7 Barrak I, Urbán E, Turzó K, Nagy K, Braunitzer G, Stájer A. Short and LongTerm Influence of Fluoride-Containing Prophylactics on the Growth of Streptococcus mutans on Titanium Surface. Implant Dent 2015;24(06):675-679

8 Gonçalves NCLAV. Fatores relacionados ao desenvolvimento de cárie dental [Internet]. In: Odontologia em saúde coletiva [monografia]. Piracicaba: Universidade Estadual de Campinas; 2002. p. 1-34 [citado 2016 Ago 09]. Disponível em:http://www.bibliotecadigital.unicamp.br/document/?down $=000778035$

9 Flink H, Tegelberg A, Thörn M, Lagerlöf F. Effect of oral iron supplementation on unstimulated salivary flow rate: a randomized, double-blind, placebo-controlled trial. J Oral Pathol Med 2006;35(09):540-547

10 Tomasin L, Pusinanti L, Zerman N. The role of fluoride tablets in the prophylaxis of dental caries. A literature review. Ann Stomatol (Roma) 2015;6(01):1-5

11 Emamieh S, Khaterizadeh Y, Goudarzi H, Ghasemi A, Baghban AA, Torabzadeh $\mathrm{H}$. The effect of two types chewing gum containing casein phosphopeptide-amorphous calcium phosphate and xylitol on salivary Streptococcus mutans. J Conserv Dent 2015; 18(03):192-195

12 Li X, Zhong Y, Jiang X, et al. Randomized clinical trial of the efficacy of dentifrices containing $1.5 \%$ arginine, an insoluble calcium compound and $1450 \mathrm{ppm}$ fluoride over two years. J Clin Dent 2015;26(01):7-12

13 Ribeiro CC, Ccahuana-Vásquez RA, Carmo CD, et al. The effect of iron on Streptococcus mutans biofilm and on enamel demineralization. Braz Oral Res 2012;26(04):300-305

14 Moslemi M, Sattari M, Kooshki F, et al. Relationship of salivary lactoferrin and lysozyme concentrations with Early Childhood Caries. J Dent Res Dent Clin Dent Prospect 2015;9(02):109-114

15 Shoji M, Takeshita T, Maruyama F, Inaba H, Imai K, KawadaMatsuo M. [Recent advances in the field of oral bacteriology]. Nippon Saikingaku Zasshi 2015;70(02):333-338

16 O'Brien KO, Nathanson MS, Mancini J, Witter FR. Calcium absorption is significantly higher in adolescents during pregnancy than in the early postpartum period. Am J Clin Nutr 2003;78(06): 1188-1193

17 Kalkwarf HJ, Specker BL. Bone mineral changes during pregnancy and lactation. Endocrine 2002;17(01):49-53

18 Nyvad B, Machiulskiene V, Baelum V. Construct and predictive validity of clinical caries diagnostic criteria assessing lesion activity. J Dent Res 2003;82(02):117-122

19 Associação Brasileira de Empresas de Pesquisa [Internet]. Critério de classificação econômica Brasil. 2008 [citado 2016 Jun 10]. Disponível em:http://www.abep.org/criterio-brasil

20 Vergnes JN, Kaminski M, Lelong N, Musset AM, Sixou M, Nabet C; EPIPAP group. Frequency and risk indicators of tooth decay among pregnant women in France: a cross-sectional analysis. PLoS One 2012;7(05):e33296

20 Vergnes JN, Kaminski M, Lelong N, Musset AM, Sixou M, Nabet C; EPIPAP group. Frequency and risk indicators of tooth decay among pregnant women in France: a cross-sectional analysis. PLoS One 2012;7(05):e33296

21 Kloetzel MK, Huebner CE, Milgrom P. Referrals for dental care during pregnancy. J Midwifery Womens Health 2011;56(02): $110-117$

22 Koenig MD, Tussing-Humphreys L, Day J, Cadwell B, Nemeth E. Hepcidin and iron homeostasis during pregnancy. Nutrients 2014;6(08):3062-3083

23 Lipiński P, Styś A, Starzyński RR. Molecular insights into the regulation of iron metabolism during the prenatal and early postnatal periods. Cell Mol Life Sci 2013;70(01):23-38

24 Darnton-Hill I, Mkparu UC. Micronutrients in pregnancy in low- and middle-income countries. Nutrients 2015;7(03): 1744-1768

25 Gredilla Díaz E. Anemia in obstetrics and gynecological surgery. Rev Esp Anestesiol Reanim 2015;62(Suppl 1):63-68

26 Orlov IuP, Lukach VN, Govorova NV. [Iron metabolism in women with anemia and eclampsia (Part I)]. Anesteziol Reanimatol 2014; 59(06):67-72

27 Liu L, Xiao Y, Zou B, Zhao LL. Study of the significance of iron deficiency indexes and erythrocyte parameters in anemic pregnant women and their newborns. Genet Mol Res 2015;14(02): 3501-3508

28 Ramírez-Vélez R, González-Ruíz K, Correa-Bautista J, MartínezTorres J, Meneses-Echávez JF, Rincon-Pabon D. Ferritin levels in pregnant Colombian women. Nutr Hosp 2014;31(02):793-797

29 Tiwari M, Kotwal J, Kotwal A, Mishra P, Dutta V, Chopra S. Correlation of haemoglobin and red cell indices with serum ferritin in Indian women in second and third trimester of pregnancy. Med J Armed Forces India 2013;69(01):31-36

30 Duggal MS, Chawla HS, Curzon ME. A study of the relationship between trace elements in saliva and dental caries in children. Arch Oral Biol 1991;36(12):881-884

31 Hussein AS, Ghasheer HF, Ramli NM, Schroth RJ, Abu-Hassan MI. Salivary trace elements in relation to dental caries in a group of multi-ethnic schoolchildren in Shah Alam, Malaysia. Eur J Paediatr Dent 2013;14(02):113-118

32 Featherstone JD. Prevention and reversal of dental caries: role of low level fluoride. Community Dent Oral Epidemiol 1999;27(01): 31-40

33 Bowen WH, Koo H. Biology of Streptococcus mutans-derived glucosyltransferases: role in extracellular matrix formation of cariogenic biofilms. Caries Res 2011;45(01):69-86

34 Eshghi A, Kowsari-Isfahan R, Rezaiefar M, Razavi M, Zeighami S. Effect of iron containing supplements on rats' dental caries progression. J Dent (Tehran) 2012;9(01):14-19

35 Dodds MW, Johnson DA, Yeh CK. Health benefits of saliva: a review. J Dent 2005;33(03):223-233

36 Ito T, Komiya-Ito A, Arataki T, et al. Relationship between antimicrobial protein levels in whole saliva and periodontitis. J Periodontol 2008;79(02):316-322 